\title{
Biopsy of Parathyroid Gland
}

National Cancer Institute

\section{Source}

National Cancer Institute. Biopsy of Parathyroid Gland. NCI Thesaurus. Code C51587.

Removal of parathyroid tissue for microscopic examination. 